\title{
DISCOVERING THE COULISSES OF ARTISTIC COLLABORATION: A GENETIC READING OF THE ENGLISH TRANSLATION OF SAINT-JOHN PERSE'S POEM AMERS
}

\author{
Esa Christine Hartmann ${ }^{*}$
}

University of Strasbourg, FR

\begin{abstract}
This study aims to analyse the creative process of literary collaboration and, more specifically, of collaborative translation from the theoretical and methodological perspective of genetic criticism applied to translation studies (genetic translation studies). Saint-John Perse's poem Amers (1956) was translated into English by the American translator and literary scholar Wallace Fowlie in 1957. The manuscripts of this translation, which present the main focus of this article, are kept in the archive of the Saint-John Perse Foundation in Aix-en-Provence (France), and reveal the genesis of a collaborative translation: Wallace Fowlie's manuscript is paralleled by the work of an unofficial translator, John Marshall, whose manuscript appears to be the closest to the final version. Both manuscripts show the handwritten suggestions, corrections, and variants of the poet himself. Spanning the various stages of the writing process from which the generation of this collaborative translation progressively emerges, the two manuscripts show a fascinating interaction. Saint-John Perse constantly confronts the versions of his two translators, sculpting them according to his poetic art. $\mathrm{He}$ also creates numerous columns of variants in the margins that display the semantic treasure of the original expression. The reader approaching this translation from a genetic standpoint can discover the sinuous gestation of the translation process, as well as the semantic and phonetic laws that govern the poet's choices. He can also make good hermeneutic use of the poet's variants, revealing an unexpected interpretative key. Consequently, through analysis of these avant-textual discoveries, many metaphors in absentia can become metaphors in praesentia, leading to a better understanding both of the original poem and its translation.

Keywords: Genetic Criticism; Translation Studies; Collaborative Translation; Closelaboration.
\end{abstract}

\footnotetext{
"Assistant Professor of French and German at the University of Strasbourg (France), and associated member of the research group Multilingualism, Translation, Creation of the ITEM/ CNRS (Paris, France), as well as member of the research group European Multilingualism of the laboratory LiLPa at the University of Strasbourg (France). Her research interests include genetic criticism and translation studies applied to French, English and German poetry of the nineteenth and twentieth centuries. Her e-mail address is esahartmann@yahoo.fr.
} 
Et vous pouvez me dire:

Où avez-vous pris cela? -

Textes reçus en langage clair!

Versions données sur deux versants!

(Saint-John Perse, Vents, II, 6) ${ }^{1}$

In many cases, artistic collaborations remain secret for a long time, and only the discovery of the authors' pre-textual documents may reveal the fascinating coulisses of collaborative creation. The analysis of the translators' drafts here proposed aims to explore the creative process of translation, which we define as the coming into being of the translator's text with all its thematic, stylistic, rhythmical and ideological aspects. ${ }^{2}$ Like the manuscript of the original text, the translator's draft shows the sinuous evolution of textual (and translingual) gestation, with "its blanks and its halts, its hesitations and its bifurcations". ${ }^{3}$ In fact, "the working documents of the translator conserve the traces of his translation process, i.e. the inscription of the various stages of his working experience [...]. These documents are situated in the coulisses of the translator's laboratory, which reveals to be an open and occulted space beyond its circumscribed space - like the genetic space."

Attempting to establish a "microhistory of translation", 5 our analysis of the collaborative translation process of Amers / Seamarks will follow the method of genetic criticism, according to the recent emergence of a new field of research located at the intersection of genetic criticism and translation studies: genetic translation studies ${ }^{6}$. The purpose of this new transdisciplinary approach is to analyse the practices of the "working translator and the evolution, or genesis, of the translated text by studying translators' manuscripts, drafts and other working documents." At the same time, as Sergio Romanelli puts it, "such analysis examines translation manuscripts in order to expound the creative process of the translator seen as a true authoring process that serves to demystify deeply rooted stereotypes about the work of the translator. ${ }^{\text {"8 }}$

Considering the English translations of Saint-John Perse's poetic work, ${ }^{9}$ the analysis of the translators' manuscripts, which are heavily annotated by the poet, shed light on the genetic process of collaborative translation and its scriptural procedures. ${ }^{10}$ Since the sole reading of the published text of these translations would never have disclosed such an invisible artistic collaboration between SaintJohn Perse and his translators, this article aims to explore the sinuous gestation of a threefold artistic collaboration through a genetic study of the English translation of Saint-John Perse's poem Amers (1956).

In 1957 Saint-John Perse's poem Amers was translated into English by the American translator and literary scholar Wallace Fowlie, and published by Bollingen Series, Pantheon Books, New York, during Saint-John Perse's exile in Washington. The manuscripts of this translation, which present the main focus of this article, are kept in the archive of the Saint-John Perse Foundation in Aix-enProvence (France), and reveal the genesis of a collaborative translation: although this translation is attributed to Wallace Fowlie, professor of Romance Languages 
at Duke University, the manuscripts that gave birth to this translation show another reality - the reality of an exceptional, collective translation.

In fact, Seamarks arose from the parallel works of two American translators: Wallace Fowlie's manuscript is paralleled by the work of an unofficial translator, John Marshall, whose manuscript appears to be the closest to the final version. Both manuscripts show the hand-written suggestions, corrections, and variants of the poet himself. Moreover, these two translators were helped by two other cotranslators: Saint-John Perse himself, who proposed his own translation variants in order to find the most fitting expression, as well as Mina Curtiss, the poet's lady friend and Maecenas, who inscribed Marshall's version into the interlinear spaces of Fowlie's manuscript, and often offered her linguistic advice when choosing the "best translation".

Spanning the various stages of the writing process from which the generation of this collaborative translation progressively emerges, the two manuscripts show a captivating interaction. Saint-John Perse constantly confronts the versions of his two translators, sculpting them according to his poetic art. He also creates numerous columns of variants in the margins that display the semantic treasure of the original expression.

Approaching this translation from a genetic standpoint hence allows us to follow the sinuous gestation of the translation process, as well as the semantic and phonetic laws that govern the poet's choices. We can also make good semantic use of the poet's variants, which reveal an unexpected interpretative key, since SaintJohn Perse's self-translation process shows the underpinnings of his poetics, both in the French text and in the English translation. Accordingly, our analysis of the two parallel manuscripts will follow three different perspectives.

The first part of this article follows a genetic approach, tracing the different stages and movements of the collective translation process. The second part represents a semantic analysis of the different variants, leading to clarify some difficult metaphors in the French poem. Lastly, the third part, entitled poetic approach, aims to elaborate a poetics of this collaborative translation of the poem Amers.

\section{The genesis of a collaborative translation process}

The following examination of the collaborative translation process will focus on one long stanza of the poem Seamarks, called "Narrow are the vessels" [Étroits sont les vaisseaux]. In order to analyse the different stages of the translation process, we need to establish the chronological order of the two parallel typescripts produced by Wallace Fowlie and John Marshall, as well as the chronological order of the various layers of variants and corrections inscribed. ${ }^{11}$ Therefore, we have adopted a reverse direction, following backward step by step the genesis of the translation.

In fact, Fowlie's typescript shows two different interlinear writings - the first, rather large pencil handwriting belongs to Mina Curtiss, the poet's friend, who inscribes here the version of the translation by John Marshall and so facilitates 
a direct confrontation of the two parallel translations on one single page. The second black ink handwriting, which is smaller and narrower, belongs to the poet Saint-John Perse, as well as the variants that appear in the left margin of the typescript. Additionally, the entire text is underlined by Saint-John Perse's black ink pen, choosing and validating each time the most adapted solution between the typed text by Fowlie, the inscribed interlinear text by Marshall, and the poet's own suggestions with black ink.

On the other hand, John Marshall's typescript only shows one single kind of notations with black ink, which appear in the interlinear space. When comparing the two parallel typescripts with the final, published version, John Marshall's version, corrected by Saint-John Perse, appears to be the final stage of the translation process. Only very little differences emerge from this comparison, one misinterpretation excepted: Marshall proposed "stallion" for étalon, which had to be replaced by "standard", corresponding to the initial version by Fowlie. Some minimal modifications correspond to Fowlie's version, revealing the fact that the final stage of the translation as presented by Marshall's typescript bearing the poet's corrections had been revised once more by the official translator Wallace Fowlie before going into print.

Saint-John Perse's corrections on the final typescript by John Marshall have been elaborated on Wallace Fowlie's translation, which presents thus a preivous stage within the collective translation process. In point of fact, the analysis of Saint-John Perse's corrections needs a comparative back and forth between the two parallel translations. Additionally, we have to consider the advice of Mina Curtiss, who inscribes Marshall's solutions into the interlinear spaces on Fowlie's manuscripts, telling us whenever she prefers Fowlie's formulations while commenting "I like this better". Mostly, these preferences of Mina Curtiss reveal a misinterpretation in Marshall's translation, such as his "inhabitable" for the French inhabitable, which is in fact a faux-ami to be translated by uninhabitable in English (MS Fowlie, 16). In one case, Mina Curtiss proposes a translation herself, writing: "Pierre [Saint-John Perse's nickname], John has "disquiet heart". I like "unquiet" better" (MS Fowlie, 40). The poet actually always follows her advice.

Going from the two parallel versions present on Fowlie's typescript, SaintJohn Perse elaborates his own, definitive solutions with his black ink pen. The coming into being of these corrections can be observed in the paradigms of variants in the margins, revealing the progressive elaboration of the most fitting expression through a list of synonyms. As a synthesis of the suggestions of four translators - Fowlie, Marhall, Curtiss and Saint-John Perse - , this definitive version is underlined on Fowlie's typescript, before being written as a correction on Marshall's typescript. Thus, the poet's corrections on Marshall's document are posterior to the ones we encounter of Fowlie's document, and represent the final synthetic state of a lexical research that has taken place on the official translator's typescript. The American translation published in the Bollingen Series represents therefore a result of a collective translation that emerged from the dialectical confrontation of four translation works. Consequently, the manuscript page 
sometimes looks like a battle field, where the different versions intertwine, interweave, intermingle, and interconnect.

\section{From genetics to semantics of translation}

Most interestingly, the poet's paradigm of variants in the margins of Fowlie's manuscript shows the micro-genesis of the translation process, transforming the textual margin into a space of both lexical and rhythmical invention and experimentation, which may be considered as the principal moment of the poetic translation process. We have tried to follow the poet's methodical research of the most fitting translation, beginning with an organisation of the poetic material through semantic approximation, and leading to the final selection of the definitive expression. Afterwards, the selected expression is inserted into the text, moving from the virtual margin into the actualized centre of the manuscript page, where it figures as a correction. Consequently, the paradigms of variants in the margins show the dynamic process of a translingual emergence of sense, and represent a semantic guide for the comprehension both of the original French text and the English translation.

At present, we would like to analyse some of these paradigms of variants which Saint-John Perse inscribes in the margins of Fowlie's typescript. These paradigms seem to function according to the principle of analogy. Consequently, they offer a semantic key for the interpretation of difficult passages, since the different meanings of the French expression are progressively elaborated through the semantic deploying of a list of translingual variants.

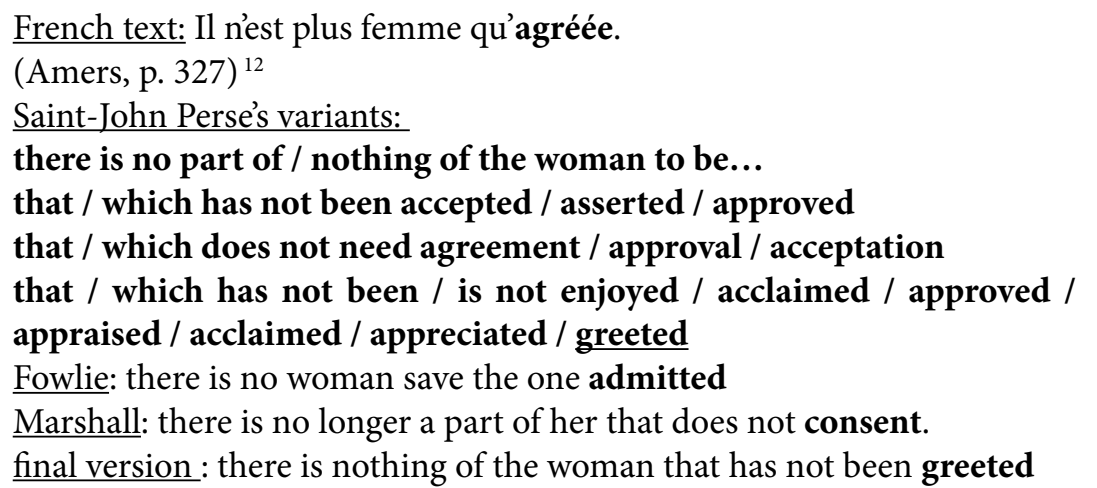

The polysemy and abstraction of the French expression femme...agréée in this passage is concretized by the paradigm of English variants that accumulates its different semantic elements: accepted / asserted / approved / acclaimed / appraised / appreciated / enjoyed / greeted...woman. The English expression chosen by the poet creates a phonetic analogy ([gr]) with the French expression: agréée - greated. Additionally, both the French and English expressions create a phonetic link towards the metaphorical dimension that governs the whole poem, associating the body of the beloved woman with the greement [the rigging] of the vessel, carrying the lovers on the sea waves: agréée - gréement - greated. 
The following example illustrates the semantic development of the French expression mêlée through a paradigm of variants in the English language:

French text : l'Amant tient l'Amante comme une mêlée d'astres

(Amers, p. 336)

Paradigm of Saint-John Perse's variants ${ }^{13}$

throng / crush / bunch / herd / flock / group / body / gang / band / gathering / group / bunch

Fowlie: "like a contest of stars"

Marshall: "like a clash of stars"

Corrected version: "and the Lover holds the Woman like a mêlée of stars."

The corrected version ignores all of the poet's suggestions and variants, and finally borrows a French word, which makes us think that the translator is cheating. Or is the word mêlée untranslatable? The English variants contest and crash, employed by the two translators, underline over all the semantics of violence and aggression, whereas the expressions gathered by Saint-John Perse in the paradigm show the predominant semantics of a multitude, composed of different unities: throng / crush / bunch / herd / flock / group / body / gang / band / gathering / group / bunch. According to its etymological meaning, the word mêlée, descending from the latin word misculare, micere "to mix", connects the meanings of multitude and mixture, disorder and of movement, without necessarily including the meaning of violence.

Similarly, the following paradigm of variants of Saint-John Perse explicates the meaning of the metaphor tête carénée in the French text:

\author{
French text : l'amour à tête carénée \\ (Amers, p. 337) \\ paradigm of Saint-John Perse : \\ hull / carina / keel / stream-line \\ carinate / keeled / faired / sheer \\ Fowlie: love with its keel-shaped head \\ Marshall: love with sleek head \\ Corrected version : love with faired head
}

The meaning of the metaphor develops from the metonymical transfer between the stream-lined form of the shape of the vessel, compared to the "head of Venus / love" (we can speak here of a mythological allegory of love), and its metaphorical characteristics of sharpness and perspicacity. The expression faired in the final version, whose first meaning addresses the sharpened form of the vessel, seems also to keep in mind the echo of the adjective fair, meaning beautiful.

The metaphorical link between the body of the beloved woman and the form of the vessel that carries the lovers on the sea emerges once more in the following passage: 
French text: Heureuse la courbe qui s'inscrit au pur délice de l'amante. (Amers, p. 348).

variants of Saint-John Perse:

bay / [gulf] / harbour

Fowlie and Marshall: "Happy the curve which is inscribed in the pure delight of the Mistress."

Corrected version: "Happy the curve inscribed in the pure delight of the woman who loves."

Saint-John Perse's variants, bay, gulf, harbour, cannot be considered as a faithful translation of the French expression courbe, exactly rendered by curve in the English version of Fowlie and Marshall. Nevertheless, the poet's variants interpret and explicit the metaphorical link between the marine landscape and the body of the beloved woman, and so, hint at the metaphorical network that carries the whole poem.

Consequently, through analysis of these pre-textual discoveries, many metaphors in absentia can become metaphors in praesentia, leading to a better understanding both of the original poem and its translation.

\section{Towards a poetics of collaborative translation}

In our last approach, which might be called poetic approach, we would like to observe how the poeticity of the French text is reproduced in the English translation. In fact, despite his attempts of self-translation, Saint-John Perse considered his poetry as utterly untranslatable. In his letter to Archibald MacLeish, written in 1941, he wrote: "By the way, I am not sure at all if such an oeuvre could be published in French in the US. On the other hand, it would be untranslatable: not only in its intellectual form, with its abstractions, ellipses and ambiguities, but also in its physical dimension, with its alliterations, its assonances and its incantations, that often imitate the rhythm of the sea and its waves, and, at last, in its literal aspect, with the etymological resources of some words." ${ }^{14}$

Speaking about the difficulties of every poetic translation, Saint-John Perse posits the specificity of his poetics that challenges the translators of his oeuvre. Consequently, the various aspects composing Saint-John Perse's style - the lexical ones (abstractions, ellipses, etymology and ambiguities), as well as the syntactical and the metrical ones (the rhythm of the waves and incantations), as well as the poetic ones (alliterations and assonances) - also represent the main aspects of the poet's suggestions and modifications within the translation process.

Accordingly, Saint-John Perse prefers to keep within the English expression the etymology of the French word. For example, he prefers leather bands to leather straps for bandes de cuir, he chooses haunch instead of hips or flanc to translate hanche, and the word écaille should be translated by scale, rather than by shell.

Other modifications of the English translation follow a metrical order, since Saint-John Perse tries to recreate the rhythmical cadence of the French poem. Let us have a glance at the following passage: 
French text : où croissent les monstres, les héros

(Amers, p.332).

Fowlie and Marshall: where monsters and heroes grow

Saint-John Perse's correction: where wax the monsters, the heroes

Saint-John Perse reproduces in his correction the word order of the French text, as well as the octosyllabic rhythm and the iambic metre:

$-\quad /\left({ }_{-}\right)$
où croissent les monstres

$$
\begin{aligned}
& - \\
& \text { where wax the monsters }
\end{aligned}
$$

Moreover, the verb wax instead of grow allows to create a beautiful alliteration in $[w]$ (where wax), underlining the growing of the sea waves.

The musicality of the translated poem constitutes thus an important criterion motivating the poet's choices and corrections. Consequently, he tries to reproduce the assonances of the French poem within the English text, underlining the deepness of the human soul compared to the deepness of the ocean:

French text: qui t'ouvre en nous ses voies de mer (Amers, p.332).

Marshall : who for you opens in us his seaways Fowlie: who opens up in us to you his ways of the sea

Saint-John Perse's correction: who opens to you the seaways deep in us

In the same way, he tries to recreate the alliterations of the French text within the English version of his poem:

French text: et mes mains ont licence parmi l'attelage de tes muscles » (Amers, p.331).

Marshall: and my hands are licensed in the teaming of your muscles Fowlie: and my hands have permission among the harnessing of your muscles

Saint-John Perse's correction: and my hands hold licence among the harness of your muscles

The alliterations in $[\mathrm{h}]$ and in $[\mathrm{m}]$ not only express here the erotic contact between the lovers, but also the continuous rhythm of the sea waves, rocking the lovers' vessel.

The poetics of Saint-John Perse are certainly rendered more explicit through the poet's participation in this collaborative translation, which challenges his text from a translingual perspective, and explores its possibilities of translatability. This self-translating face to face with the original French text appears to be a recreation or secondary creation, repeating the genesis of the oeuvre premiere. This recreation process is paralleled by a semantic feature, since the poet reveals to be the creator as well as the interpreter of his works.

Certainly, one might question the status and understanding of authorship within this complex closelaboration, as the Cuban writer Guillermo Cabrera 
Infante calls this intimate relationship between author and translator, who elaborate together the nascent text of the translation..$^{15}$ How did the translators perceive the poet's dominant supervising of their work? How could they tolerate his function as an exigent co-translator? Unfortunately, the Saint-John Perse Foundation does not keep any significant correspondence between Saint-John Perse and his translators W: Fowlie and J. Marshall as a testimony of their personal relationship or as an exchange of views on their collective translation work.

However, the famous poet T.S. Eliot, translator of Saint-John Perse's poem Anabase (1924), seems to take advantage of the complex and often reverse relationship between poet and translator that governs their closelaboration, since he states the following in his preface to his Anabasis (1930): "As for the translation, it would not be even so satisfactory as it is, if the author had not collaborated with me to such an extent as to be half-translator". ${ }^{16}$

On the other hand, translation itself might be understood as an intrinsic collaborative process, as the famous French translator M.-E. Coindreau posits it: "Traduire est un acte d'amoureuse collaboration. Le traducteur et son auteur doivent interpréter sans cesse la fable de l'Aveugle et du Paralytique: je marcherai pour vous, vous y verrez pour moi. "17 [Translation is an act of amorous collaboration. The translator and his author have to interpret unceasingly the fable of the Blind and the Lame: I shall march for you, and you will see for me.]

Nevertheless, the discovery of the secret coulisses of artistic collaboration certainly shows the dynamic and enriching phenomena of a translingual exchange. Moreover, the collaborative translation process of Amers / Seamarks reveals the esthetical and ideological keystones of the poem, as well as the poetics both of the French text and its translation into English.

Notes

1. Saint-John Perse, CEuvres complètes, Paris, Gallimard, coll. « Bibliothèque de la Pléiade », 1972, 213.

2. Cf. our previous publications in genetic translation studies : Esa Christine Hartmann, «Genèse d'une traduction collaborative: Winds de Hugh Chisholm et Saint-John Perse», in : Au miroir de la traduction: avant-texte, intratexte, paratexte, E. Hartmann et P. Hersant (ed.), Paris, Editions des Archives Contemporaines, 2018 ; « Traduire avec l'auteur: T.S.Eliot et Saint-John Perse », in: Traduire avec lauteur. Textes et documents, P. Hersant (ed.), Paris, PUPS, 2018 ; "Traduction, interprétation et critique. Les traductions anglaises et allemandes des poèmes de Saint-John Perse à l'épreuve de l'imagination créatrice ", Saint-John Perse et lécho des langues. Poésie et traduction, La nouvelle anabase, Revue détudes persiennes, n5, Paris, L'Harmattan, octobre 2009, 233-299; " Histoire d'une traduction », Souffle de Perse, $\mathrm{n}^{\circ}$ 9, Publication de la Fondation Saint-John Perse, janvier 2000, 11-27.

3. Almuth Grésillon, La mise en œuvre. Itinéraires génétiques, Paris, CNRS éditions, 2008, 40 (our translation).

4. Marie-Hélène Paret-Passos, "De Finnegans Wake à Finnicius Revém. Approche génétique des cahiers de travail d'un traducteur ", Genesis. Revue internationale de critique génétique, special issue Traduire, Fabienne Durand-Bogaert (ed.) Paris, PUPS, 38/14, 2014, 69 (our translation). 
5. As Jeremy Munday posits it, microhistories of translation deal with translators' material imprints - personal papers, manuscripts, typescripts, proofs, handwritten marginalia, private library, letters, interviews and other related textual testimonies (avant-textes) that provide insight into their performance. (Jeremy Munday, "Using primary sources to produce a microhistory of translation and translators: theoretical and methodological concerns", Translator: Studies in Intercultural Communication, 20.1, 2014, 64-80).

6. Genetic translation studies were first explored, illustrated and conceptualized in the following publications: Marie-Hélène Paret Passos, Da crítica genética à tradução litéraria: uma interdisciplinaridade, Vinhedo, Horizonte, 2011, and Sergio Romanelli, Gênese do processo tradutório, Vinhedo, Horizonte, 2013.

7. Antony Cordingley \& Chiara Montini, "Genetic translation studies: an emerging discipline", Linguistica Antverpiensa, New Series: Themes in Translation Studies, $14,2015,1$.

8. Sergio Romanelli, "Manuscripts and translations: Spaces for creation", Linguistica Antverpiensa, New Series: Themes in Translation Studies, 14, 2015, 88.

9. Saint-John Perse was a French poet and diplomat (1887-1975), who was awarded the Nobel Prize in Literature in 1960.

10. For an integral and exhaustive analysis of Saint-John Perse's manuscripts, cf. Esa Christine Hartmann, Les manuscrits de Saint-John Perse. Pour une poétique vivante, Paris, L'Harmattan, 2007.

11. We have established a formal description of the manuscripts of the English translation "Narrow are the ships". First, Fowlie's typescript (MS Fowlie) is composed of 44 numbered sheets. The first page bears the title "Narrow are the ships", corrected by Saint-John Perse into "Narrow are the vessels". The typescript shows two different interlinear annotations: one large handwriting with a pencil, one small and narrow handwriting with a black ink pen. The first one belongs to Mina Curtiss, the second one to Saint-John Perse. The latter also appears in the left margin, where numerous vertical lists of variants accumulate. The entire text is underlined with black ink. Second, Marshall's typescript (MS Marshall) is composed of 48 numbered sheets and shows one single kind of annotations with black ink, which belongs to Saint-John Perse and appears in the interlinear spaces. The first page (title page) bears the following comment by Saint-John Perse: "Traduction de Marshall corrigée pour révision de la traduction de Fowlie et létablissement du texte anglais final à renvoyer à Fowlie (Giens, 1957)» [Marshall's translation corrected for the revision of Fowlie's translation et the establishment of the final English version to be sent to Fowlie]. The same page bears the title "Narrow are the vessels", accompanied by the typed mention: "A translation for the author in four numbered copies: No 1, JM, Easter 1957". The end of the typescript bears the following reference: "October 1956-April 1957".

12. All citations of the French text refer to the edition of the complete works of Saint-John Perse, Cuuvres complètes, Paris, Gallimard, coll. « Bibliothèque de la Pléiade », 1972.

13. Saint-John Perse's variants are cited from Fowlie's manuscript (MS Fowlie).

14. Saint-John Perse, Letter to Archibald MacLeish, September 9th, 1941, Euvres complètes, Paris, Gallimard, coll. « Bibliothèque de la Pléiade », 1972, 548.

15. S.J. Levine, The Subversive Scribe. Translating Latin American Fiction, Saint-Paul, Graywolf Press, 1991, XIII:

16. T.S. Eliot, "Preface", Anabasis, a poem by St-J. Perse with a Translation into English by T.S. Eliot, London, Faber and Faber, 1930, 10-11. 
17. M.E. Coindreau, Mémoires d'un traducteur. Entretiens avec Christian Giudicelli, Paris, Gallimard, 1992, 137.

References

\section{Primary sources:}

Saint-John Perse, Euvres complètes, Paris, Gallimard, coll. « Bibliothèque de la Pléiade », 1982.

Saint-John Perse, Seamarks, translated by Wallace Fowlie, New York, Pantheon Books, Bollingen Series, 1958 (bilingual edition).

\section{Secondary sources:}

Anokhina, Olga, "Traduction et réécriture chez Vladimir Nabokov : genèse d'une œuvre en trois langues ", Genesis. Revue internationale de critique génétique, special issue Traduire, Fabienne Durand-Bogaert (ed.) Paris, PUPS, 38/14, 2014, 111-127.

Coindreau, Maurice-Edgar, Mémoires d'un traducteur. Entretiens avec Christian Giudicelli, Paris, Gallimard, 1992.

Cordingley, Anthony \& Frigau Manning Céline (dir.), Collaborative translation: from the Renaissance to the Digital Age, London, Bloomsbury, 2016.

Cordingley, Anthony \& Montini Chiara, "Genetic translation studies: an emerging discipline", Linguistica Antverpiensa, New Series: Themes in Translation Studies, 14, 2015, 1-18.

De Biasi, Pierre Marc, La génétique des textes, Paris, Nathan, 2000.

Durand-Bogaert, Fabienne (ed.), Traduire, special issue of Genesis, Revue internationale de critique génétique, 38/14, Paris, PUPS, 2014.

Elbaz, Shlomo, T. S. Eliot et Saint-John Perse, face à face et face au désert, thèse de doctorat, Université hébraïque de Jérusalem, 1973.

Elbaz, Shlomo, « T. S. Eliot vu et corrigé par Saint-John Perse », Espaces de Saint-John Perse, $\mathrm{n}^{\text {os }} 1$-2, Publications de l'Université de Provence, 1979, 129-150.

Eliot, Thomas Stearns, "Préface pour une édition anglaise d'Anabase ", dans Jean Paulhan (dir.), Honneur à Saint-John Perse, Paris, Gallimard, 1965, 420-422.

Gresillon, Almuth, La mise en ouvre. Itinéraires génétiques, Paris, CNRS Editions, 2008.

Eléments de critique génétique. Lire les manuscrits modernes, Paris, CNRS Editions, 2016 [1994].

Hartmann, Esa Christine : Les Manuscrits de Saint-John Perse. Pour une poétique vivante, Paris, L'Harmattan, 2007.

" "Traduction, interprétation et critique. Les traductions anglaises et allemandes des poèmes de Saint-John Perse à l'épreuve de l'imagination créatrice », Saint-John Perse et l'écho des langues. Poésie et traduction, La nouvelle anabase, Revue d'études persiennes, $\mathrm{n}^{\circ}$ 5, Paris, L'Harmattan, octobre 2009, 233-299.

. "Histoire d'une traduction ", Souffle de Perse, n 9, Publication de la Fondation Saint-John Perse, janvier 2000, 11-27.

. «Genèse d'une traduction collaborative : Winds de Hugh Chisholm et SaintJohn Perse ", in : Au miroir de la traduction : avant-texte, intratexte, paratexte, E. Hartmann et P. Hersant (dir.), Paris, Editions des Archives Contemporaines, 2018. 
« Traduire avec l'auteur: T.S.Eliot et Saint-John Perse », in: Traduire avec lrauteur. Textes et documents, P. Hersant (éd.), Paris, PUPS, 2018.

Hartmann, Esa Christine \& Hersant Patrick (ed.), Au miroir de la traduction : avanttexte, intratexte, paratexte, Paris, Editions des Archives Contemporaines, 2018.

Hersant, Patrick, "Author-translator collaborations : a typological survey ", in Anthony Cordingley et Céline Frigau Manning (dir.), Collaborative translation : from the Renaissance to the Digital Age, Londres, Bloomsbury, 2016.

John-Steiner, Vera, Creative collaboration, New York, Oxford University Press, 2000.

Levillain, Henriette, Sur deux versants. La création chez Saint-John Perse d'après les versions anglaises de son œuvre poétique, Paris, Corti, 1987.

"Saint-John Perse. Traducteur en langue anglaise de son œuvre. Problématique d'analyse critique ", dans Michel Ballard (dir.), La Traduction plurielle, Lille, Presses Universitaires de Lille, 1990, 33-45.

Levine, Suzanne Jill, The Subversive Scribe. Translating Latin American Fiction, SaintPaul, Graywolf Press, 1991.

Little, Roger, «T. S. Eliot and Saint-John Perse », The Arlington Quarterly Review, University of Texas, vol. II, $\mathrm{n}^{\circ}$ 2, 1969.

Montini, Chiara (ed.), Traduire. Genèse du choix, Paris, Editions des archives contemporaines, 2016.

Munday, Jeremy, "Using primary sources to produce a microhistory of translation and translators: theoretical and methodological concerns", Translator: Studies in Intercultural Communication, 20.1, 2014, 64-80).

Rigolot, Carol, «Introduction », dans Saint-John Perse, Lettres atlantiques, Saint-John Perse, T. S. Eliot, Allen Tate (1926-1970), éd. Carol Rigolot, Cahiers Saint-John Perse, ${ }^{\circ}$ 17, Paris, Gallimard, 2006, 7-27.

Romanelli, Sergio, Genese do processo tradutório, Vinhedo, Horizonte, 2013.

"Manuscripts and translations: Spaces for creation", Linguistica Antverpiensa, New Series: Themes in Translation Studies, 14, 2015, 87-104.

Paret-Passos, Marie-Hélène, Da crítica genética à tradução litéraria: uma interdisciplinaridade, Vinhedo, Horizonte, 2011.

Marie-Hélène, "De Finnegans Wake à Finnicius Revém. Approche génétique des cahiers de travail d'un traducteur", Genesis. Revue internationale de critique génétique, special issue Traduire, Fabienne Durand-Bogaert (ed.) Paris, PUPS, 38/14, 2014, 69-83.

Sperti, Valeria, "La traduction littéraire collaborative entre privilège auctorial et contrôle traductif ", in L'Autotraduction littéraire. Perspectives théoriques, A. Ferraro et R. Grutman (dir.), Paris, Classiques Garnier, 2016, 169-188.

Recebido em: 05/12/2017

Aceito em: 17/04/2018 